\title{
PERAN REGULASI DIRI DAN KECERDASAN INTELEKTUAL (IQ) TERHADAP PRESTASI AKADEMIK (STUDI PADA MAHASISWA PROGRAM MENTORING DI UNIVERSITAS X TANGERANG)
}

\author{
Julia Rostaulina Tarigan ${ }^{1}$, Sri Tiatri ${ }^{2}$, Heni Mularsih ${ }^{1}$ \\ ${ }^{1}$ Fakultas Psikologi, Universitas Tarumanagara Jakarta \\ Email:jtarigan02082011@gmail.com \\ ${ }^{2}$ Fakultas Psikologi, Universitas Tarumanagara Jakarta \\ Email: sri.tiatri@untar.ac.id \\ ${ }^{3}$ Fakultas Psikologi, Universitas Tarumanagara Jakarta \\ Email: henim@mku.untar.ac.id
}

\begin{abstract}
Self-regulation and intellectual intelligence in previous studies indicate that these two variables influence academic achievement. However, most studies of the three variables were carried out on subjects in the middle school category, and research using self-regulation and intellectual intelligence variables carried out on university students is very rare, therefore, this fact piqued the researchers' interest in conducting this research. The study was conducted to determine the extent to which self-regulation and intellectual intelligence play a role in the academic achievement of university students who took part in the mentoring program at X University Tangerang. This research uses quantitative methods. The sampling technique was carried out by purposive sampling technique, and participants were obtained with the criteria as such: university students participating in the mentoring program, acting as mentees with <2.00 GPA, with a total of 47 mentees obtained as participants. The measurement of the selfregulation variable is done using an adaptation of the self-regulation questionnaire developed by Brown and Miller (1991), while the measurement of intellectual intelligence uses the CFIT test tool. The variable of academic achievement is measured using the participant GPA in the odd semester of 2017/2018. Data analysis was performed using multiple linear regression tests on SPSS version 17. The result of the study indicates that self-regulation and intellectual intelligence do not play a role in gaining academic achievement for students who acted as mentees in the mentoring program at $\mathrm{X}$ University Tangerang. This shows that low academic achievement among the participants of this study was caused by other factors not examined in this study.
\end{abstract}

Keywords: Academic Achievement, Self Regulation, and Intellectual Intelligence

\begin{abstract}
ABSTRAK
Kemampuan regulasi diri dan kecerdasan intelektual pada penelitian terdahulu menunjukkan bahwa kedua variabel ini berpengaruh terhadap prestasi akademik. Namun, kebanyakan penelitian terhadap ketiga variabel tersebut dilakukan pada subyek dengan kategori siswa sekolah menengah, dan masih sangat jarang penelitian dengan menggunakan variabel regulasi diri dan kecerdasan intelektual dilakukan pada mahasiswa, sehingga hal ini juga turut membuat peneliti tertarik untuk melakukan penelitian ini. Penelitian dilakukan untuk mengetahui sejauhmana regulasi diri dan kecerdasan intelektual berperan terhadap prestasi akademik mahasiswa yang mengikuti program mentoring di Universitas X Tangerang. Penelitian ini menggunakan metode kuantitatif. Teknik pengambilan sampel dilakukan dengan teknik purposive sampling, sehingga diperoleh partisipan dengan kriteria mahasiswa yang mengikuti program mentoring, berperan sebagai mentee dan IPK <2.00, dengan total 47 orang mentee yang diperoleh sebagai partisipan. Pengukuran variabel regulasi diri dilakukan dengan menggunakan adaptasi kuesioner regulasi diri yang dikembangkan oleh Brown and Miller (1991), sementara pengukuran kecerdasan intelektual menggunakan alat tes CFIT. Variabel prestasi akademik diukur menggunakan IPK partisipan pada semester ganjil 2017/2018. Analisis data dilakukan dengan menggunakan uji regresi linier berganda pada program SPSS versi 17. Hasil penelitian menemukan bahwa kemampuan regulasi diri dan kecerdasan intelektual tidak berperan terhadap pencapaian prestasi akademik mahasiswa yang berperan sebagai mentee pada program mentoring di Universitas X Tangerang. Hal ini menunjukkan bahwa pada pencapaian prestasi akademik yang rendah pada partisipan penelitian ini disebabkan oleh faktor lain yang tidak diteliti dalam penelitian ini.
\end{abstract}

Kata kunci: Prestasi Akademik, Regulasi Diri, dan Kecerdasan Intelektual 


\section{PENDAHULUAN \\ Latar Belakang}

Memasuki era perkembangan teknologi dan globalisasi yang semakin pesat, menuntut sumber daya manusia untuk memiliki kemampuan dan pengetahuan yang lebih. Kemampuan dan pengetahuan tersebut dapat diperoleh melalui dunia pendidikan. Oleh karena itu, sumber daya manusia diharapkan memiliki tingkat pendidikan yang cukup untuk dapat menjawab kebutuhan dari kemajuan tersebut agar memiliki peluang yang lebih besar untuk dapat memasuki dunia kerja dan mendapat lapangan pekerjaan yang layak.

Setiap individu yang mengikuti pendidikan pada perguruan tinggi, biasanya akan disebut sebagai mahasiswa. Menurut Kamus Besar Bahasa Indonesia (2005), mahasiswa adalah individu yang belajar di perguruan tinggi. Mahasiswa ini dinilai sebagai individu yang memiliki tingkat intelektualitas serta cara berfikir yang cerdas. Siswoyo (dalam Widyastuti, 2012) mengatakan bahwa mahasiswa adalah manusia yang tercipta untuk selalu berpikir yang saling melengkapi. Kebanyakan orang menjadi mahasiswa pada usia remaja akhir (usia 17-18 tahun). Pada usia ini, isu kemandirian, kehidupan yang independen dari orangtua, dan karir mulai memuncak (Newman \& Newman, 2009).

Setiap mahasiswa, dalam menjalani perkuliahannya pada umumnya juga akan memiliki kegiatan-kegiatan lain di luar perkuliahan rutinnya, semisal seperti ikut aktif dalam kegiatan berorganisasi di dalam maupun di luar kampus, bahkan ada yang kuliah sambil bekerja. Terlepas dari kegiatannya di luar kuliah, mahasiswa memiliki kewajiban dalam mengerjakan tugas-tugas akademik, berupa tuntutan penyelesaian tugas tersebut antara lain adalah membuat makalah, essay, menyiapkan presentasi maupun membuat jurnal-jurnal penelitian, membuat berbagai macam tugas akademik maupun ujian yang merupakan suatu bentuk evaluasi bagi mahasiswa yang dilaksanakan secara rutin, serta kegiatan non akademik (Mayasari, 2010).

Banyaknya kegiatan yang harus dikerjakan mahasiswa selama masa studinya di perkuliahan, tidak serta merta membuat mahasiswa tersebut fokus untuk menjalankan dan memenuhi tuntutan perkuliahannya. Selain itu, terdapat beberapa hal lain yang juga turut membuat mahasiswa cenderung kurang dapat fokus untuk menjalankan perkuliahan, seperti terlalu santai dalam mengerjakan tugas-tugas perkuliahannya, bahkan terkadang mereka tidak mengerjakan dan mengumpulkan tugas tersebut, adanya dispensasi ketidakhadiran yang diberikan kampus sebagai alternatif pengganti apabila mahasiswa harus ijin untuk tidak mengikuti perkuliahan karena alasan tertentu, serta jadwal kuliah yang tidak runut seperti saat masih di bangku sekolah.

Banyaknya kegiatan lain di luar kegiatan perkuliahan yang harus dijalani mahasiswa ini membuat mereka pada akhirnya kurang mampu memenuhi standar penilaian yang ditetapkan oleh Universitas. Setiap Universitas tentunya memiliki standar kelulusan tersendiri yang pada akhirnya akan berlaku bagi seluruh mahasiswa. Demikian halnya dengan Universitas X, yang berada Tangerang, menerapkan standar minimal prestasi akademik yang harus dicapai seluruh mahasiswanya yakni IPK (Indeks Prestasi Kumulatif) minimum 2.00.

Berdasarkan informasi yang diperoleh dari salah satu unit kemahasiswaan khususnya bagian konseling di Universitas X, diketahui bahwa mahasiswa yang tidak mampu memenuhi standar Universitas $\mathrm{X}$ setiap semesternya akan mendapatkan surat peringatan penyimpangan prestasi akademik. Pada umumnya, mahasiswa yang berprestasi rendah ini disebabkan oleh beberapa 
faktor baik dari aspek akademik maupun non-akademik. Beberapa faktor yang dapat memengaruhi mahasiswa berprestasi rendah tersebut adalah tidak adanya perencanaan akademis yang jelas terhadap studi yang sedang dijalani, ketidakmampuan untuk meregulasi diri, masalah ekonomi keluarga dan sebagainya.

Salah satu faktor personal yang memengaruhi prestasi seseorang adalah kemampuan melakukan regulasi diri (Woolfolk, dalam Husna, 2014). Brown dan Miller (1999, dalam Gavora, 2015) mendefinisikan regulasi diri sebagai suatu kemampuan untuk mengembangkan, mengimplementasikan, dan mempertahankan perilaku sebagai upaya untuk mencapai sebuah tujuan. Ketika seseorang menjadi mahasiswa, tugas dan tanggungjawabnya tidak hanya seputar diri sendiri dan keluarga, tetapi juga masyarakat. Hal-hal tersebut memengaruhi bagaimana mahasiswa menentukan tujuan, minat, atau orientasi hidupnya. Seorang mahasiswa dikatakan memiliki regulasi diri yang baik apabila ia mengetahui tujuan yang ingin ia capai dalam perkuliahannya serta mampu menentukan arah yang akan dia lakukan sehingga pada akhirnya mahasiswa tersebut berhasil mencapai tujuannya. Husna (2014) dalam jurnalnya yang berjudul "Regulasi Diri Mahasiswa Berprestasi", mengatakan bahwa proses regulasi diri melibatkan keaktifan seseorang dalam menghasilkan pikiran, perasaan dan tindakan, merencanakan serta terus-menerus mengadaptasikannya guna mencapai tujuan-tujuan.

Regulasi diri merujuk pada dilakukannya kontrol terhadap diri sendiri, terutama untuk menjaga diri tetap berada di jalur yang sesuai dengan standar yang dikehendaki (Vohs dan Baumiester, dalam Husna, 2014). Beberapa mahasiswa di Universitas X yang berada di kota Tangerang kurang mampu mempertahankan dirinya untuk tetap memenuhi standar yang ditentukan oleh Universitas $\mathrm{X}$, sehingga menyebabkan mereka kesulitan untuk menjalani perkuliahan dengan baik sehingga berdampak terhadap prestasi akademik yang mereka capai. Hal ini terlihat dari hasil konseling yang sudah dilakukan terhadap 2728 mahasiswa yang berprestasi rendah pada tahun 2017. Berdasarkan hasil konseling tersebut ditemukan fakta bahwa 57\% mahasiswa berpretasi rendah karena tidak memperhatikan ketentuan absensi dan informasi perkuliahan lainnya seperti jadwal registrasi perkuliahan, 2\% karena kurang mampu melakukan penyesuaian diri di perkuliahan, 2\% mengalami kesulitan dalam memahami materi perkuliahan, $11 \%$ memiliki masalah dengan keluarga, teman dan ekonomi, 26\% karena kesibukan lain dan belum memiliki orientasi masa depan yang jelas sehingga tidak memahami tujuan kuliahnya, 3\% tidak mau mengikuti perkuliahan karena tidak suka dengan dosen pengajar.

Regulasi diri adalah proses seseorang mengaktifkan dan memelihara pikiran, perasaan, dan tindakannya untuk mencapai tujuan personal (Zimmerman, dalam Husna, 2014); baik tujuan yang bersifat akademik, emosional, sosial (Patrick, 1997; Santrock, 2008; Woolfolk, 2010 dalam Husna, 2014), dan spiritual (McCullough and Willoughby, 2009 dalam Husna, 2014). Regulasi diri mencakup area kehidupan yang lebih luas, termasuk dalam bidang akademik. Seorang mahasiswa yang mampu melakukan regulasi diri tentunya akan cenderung berhasil dalam studi dan mencapai standar prestasi akademik yang ditentukan Universitasnya.

Menurut Brown dan Miller (1999, dalam Gavora, 2015), terdapat tujuh tahapan yang akan dilakukan seseorang saat ia berusaha melakukan regulasi diri, yaitu (1) tahap penerimaan informasi yang relevant; (2) tahap mengevaluasi informasi dan membandingkan informasi tersebut dengan norma atau standar yang berlaku; (3) memicu suatu perubahan; (4) mencari opsiopsi pilihan; (5) membentuk suatu rencana; (6) mengimpelementasikan rencana yang sudah dibuat; (7) Menguji efektifitas rencana yang sudah dilakukan. 
Kemampuan regulasi diri dibentuk melalui proses yang panjang di mana pengasuhan memiliki andil yang besar. Kemampuan regulasi diri sulit dipelajari jika seseorang dibesarkan dalam keluarga atau komunitas yang tidak mengajarkan, memberi teladan, dan menghargai regulasi diri (Zimmerman, 2000). Seseorang yang dibesarkan dalam keluarga yang menetapkan standar yang tinggi, menekankan tanggungjawab, dan pencapaian akademik diketahui memiliki kemampuan regulasi diri yang tinggi (Santrock, 1999).

Membahas mengenai prestasi akademik, tentunya tidak terlepas juga dari kecerdasan intelektual yang dimiliki mahasiswa tersebut. Kecerdasan intelektual, menurut Robins dan Judge (dalam Dwijayanti, 2009), merupakan suatu kemampuan yang dibutuhkan untuk melakukan berbagai aktifitas mental berpikir, menalar dan memecahkan masalah. Binet dan Simon dalam Dwijayanti (2009), mengatakan bahwa suatu kecerdasan intelektual sebagai suatu kemampuan terdiri dari tiga ciri, yaitu kemampuan untuk mengarahkan pikiran atau mengarahkan tindakan, kemampuan untuk mengubah arah tindakan bila tindakan itu telah dilakukan, dan kemampuan untuk mengkritik diri sendiri.

Suwardjono (dalam Artana, 2014) menyatakan bahwa belajar di perguruan tinggi merupakan suatu pilihan strategik dalam mencapai suatu tujuan individual seseorang. Semangat, cara belajar, dan sikap mahasiswa terhadap belajar sangat dipengaruhi oleh kesadaran akan adanya tujuan individual dan tujuan lembaga pendidikan yang jelas. Dalam semua aspek ini, pengukuran prestasi akademik merupakan hal yang sangat penting untuk mengetahui tingkat keberhasilan yang dicapai mahasiswa dalam belajar. Beberapa mahasiswa berdasarkan fakta yang sudah dipaparkan sebelumnya, menunjukkan bahwa mereka belum memiliki tujuan masa depan yang jelas, sehingga membuat mereka kesulitan untuk menetukan pilihan strategi, mengarahkan semangat dan cara belajar yang tepat untuk mencapai prestasi akademik yang optimal, minimal mencapai target atau standar kelulusan per-semester yang ditetapkan oleh Universitas.

Penelitian yang dilakukan Husna (2014) menemukan bahwa regulasi diri memiliki peran terhadap pencapaian prestasi mawapres. Demikian halnya penelitian yang dilakukan oleh Dita (2016) menunjukkan bahwa kecerdasan intelektual berpengaruh secara signifikan terhadap prestasi belajar siswa SMK. Hasil penemuan dalam penelitian ini membuat peneliti juga tertarik untuk melakukan penelitian dengan menggabungkan kedua faktor internal tersebut untuk melihat peran regulasi diri dan kecerdasan intelektual terhadap prestasi akademik. Selain itu, penelitian Husna (2014) dan Dita (2016) dilakukan pada subyek dengan kategori siswa sekolah menengah, dan masih sangat jarang penelitian dengan menggunakan variabel regulasi diri dan kecerdasan intelektual dilakukan pada mahasiswa, sehingga hal ini juga turut membuat peneliti tertarik untuk melakukan penelitian ini.

\section{Rumusan Masalah}

Rumusan masalah dalam penelitian ini adalah (1) apakah regulasi diri berperan terhadap prestasi akademik mahasiswa yang mengikuti program mentoring di Universitas X Tangerang? (2) apakah kecerdasan intelektual (IQ) memiliki peran terhadap pencapaian prestasi akademik mahasiswa yang mengikuti program mentoring di Universitas X Tangerang? (3) apakah regulasi diri dan kecerdasan intelektual (IQ) secara Bersama-sama berperan terhadap pencapaian prestasi akademik mahasiswa yang mengikuti program mentoring di Universitas X Tangerang? Adapun tujuan dilakukannya penelitian ini adalah untuk mengetahui sejauhmana regulasi diri dan kecerdasan intelektual (IQ) berperan terhadap prestasi akademik mahasiswa yang mengikuti program mentoring di Universitas X Tangerang. 


\section{METODE PENELITIAN}

Teknik pengambilan sampel dengan menggunakan metode purposive sampling dengan kriteria subyek adalah mahasiswa yang mengikuti perkuliahan di Universitas X Tangerang dan mengikuti program mentoring serta berperan sebagai mentee. Jumlah sampel penelitian sebanyak 47 mahasiswa dengan kategori IPK $<2.00$ berdasarkan data prestasi akademik yang diambil pada periode semester ganjil 2017/2018 (sumber data dari Student Advisory, Universitas X Tangerang).

Desain penelitian menggunakan metode penelitian kuantitatif yang merupakan suatu proses menemukan pengetahuan dengan menggunakan data berupa angka sebagai alat untuk menganalisis keterangan mengenai hal yang ingin diketahui. Pengambilan data dilakukan dengan menggunakan alat ukur variabel regulasi diri yang diadaptasi dari alat tes yang dikembangkan oleh Miller and Brown (1991), pengukuran kecerdasan intelektual (IQ) dilakukan dengan menggunakan alat tes Culture Fair Intelligence Test (CFIT), sementara pengukuran prestasi akademik dilakukan dengan menggunakan Indeks Prestasi Kumulatif (IPK) partisipan pada periode semester ganjil 2017/2018. Teknik analisa regresi berganda untuk menjawab hipotesis penelitian dilakukan dengan menggunakan aplikasi SPSS versi 17.

Pengukuran variabel regulasi diri menggunakan adaptasi alat ukur Self Regulation Questionnaire (SRQ) yang dikembangkan oleh Miller and Brown pada tahun 1991. Alat ukur ini memiliki 63 item pernyataan yang mencakup 7 aspek dari regulasi diri. Setelah melakukan 3 tahapan uji validitas, yaitu face validity, content validity dan construct validity serta uji reliabilitas, maka ditentukan bahwa 18 item dihilangkan dan 45 item tetap dapat dipertahankan. Setelah menghilangkan 18 butir item, peneliti melakukan uji reliabilitas alat ukur maka skor Cronbach's Alpha sebesar 0,812.

\section{HASIL DAN PEMBAHASAN}

Secara umum, subyek dalam penelitian ini adalah mahasiswa yang mengikuti perkuliahan di Universitas X Tangerang yang mengikuti prorgam mentoring dan berperan sebagai mentee dengan kategori Indeks Prestasi Kumulatif pada periode semester 2017/2018 adalah <2,00. Total partisipan dalam penelitian ini adalah berjumlah 47 mahasiswa.

Berdasarkan jenis kelaminnya, dari 47 mahasiswa yang menjadi partisipan terdiri dari 31 mahasiswa berjenis kelamin perempuan $(66,1 \%)$, sedangkan partisipan berjenis kelamin laki-laki ada sebanyak 16 mahasiswa $(33,9 \%)$.

Berdasarkan usianya, partisipan penelitian ini terbagi menjadi beberapa kelompok usia karena program mentoring di Universitas X Tangerang diselenggarakan bagi seluruh mahasiswa yang dianggap perlu mengikuti program mentoring, sehingga usia partisipan penelitian ini tersebar mulai dari usia 18 tahun hingga 23 tahun. Adapun pengelompokan partisipan berdasarkan usianya adalah 19 mahasiswa berusia 18 tahun (40\%), 18 mahasiswa berusia 19 tahun (38\%), 6 mahasiswa berusia 20 tahun (13\%), 1 mahasiswa berusia 21 tahun (2\%) dan 2 mahasiswa berusia 22 tahun (4\%), serta 1 mahasiswa berusia 23 tahun (2\%).

Berdasarkan jurusannya, diketahui bahwa partisipan penelitian ini didominasi oleh jurusan accounting and finance sebanyak 17 mahasiswa (38\%). Lalu diikuti jurusan International 
Business Management sebanyak 14 mahasiswa (30\%), Information Systems 5 mahasiswa (11\%), Computer Science 4 mahasiswa (9\%), Management 3 mahasiswa (6\%), New Media 2 mahasiswa (4\%), dan International Business Management Global Class 1 mahasiswa (2\%).

Berdasarkan data pengukuran variabel regulasi diri, sebagian besar partisipan dalam penelitian ini memiliki kemampuan regulasi diri sedang yaitu sebanyak 39 mahasiswa (83\%), kemampuan regulasi diri tinggi sebanyak 5 mahasiswa (11\%) dan kemampuan regulasi diri rendah sebanyak 3 mahasiswa (10\%). Berdasarkan hasil penggolongan ini dapat dikatakan bahwa Sebagian besar partisipan dalam penelitian ini sudah cukup mampu mencari informasi, melakukan evaluasi terhadap informasi yang diperoleh, membuat perubahan dalam diri, mencari alternatif solusi, membuat rencana, melaksanakan rencana yang sudah dibuat serta menilai efektifitas dari rencana yang sudah dijalankan.

Berdasarkan penggolongan kecerdasan intelektualnya, partisipan penelitian ini digolongkan ke dalam 4 (empat) kategori kecerdasan dengan sebagian besar partisipan memiliki kecerdasan intelektual (IQ) average yaitu sebanyak 32 mahasiswa (68\%), high average sebanyak 5 mahasiswa (11\%), borderline sebanyak 5 mahasiswa (11\%), Low Average sebanyak 5 mahasiswa (11\%). Artinya, sebagian besar partisipan memiliki taraf kecerdasan yang rata-rata sama dengan mahasiswa lain, sehingga mereka masih diharapkan masih dapat mengikuti kegiatan perkuliahan dengan baik.

Uji hipotesis pertama menyatakan bahwa kemampuan regulasi diri tidak berperan terhadap pencapaian prestasi akademik partisipan. Hal ini terbukti pada hasil analisa uji regresi berganda yang dapat dilihat pada tabel 1 berikut ini.

Tabel 1. Uji regresi linear berganda pada variabel regulasi diri terhadap prestasi akademik

\begin{tabular}{ccccc}
\hline Variabel & R square & $\begin{array}{c}\text { Std. Error of the } \\
\text { estimates }\end{array}$ & F & Signifikansi \\
\hline Regulasi Diri & 0.039 & 0.20594 & 1.816 & 0.184 \\
\hline
\end{tabular}

Nilai signifikansi pengaruh regulasi diri terhadap prestasi akademik sebesar 0.184. Suatu variabel dikatakan mempengaruhi variabel lain apabila nilai signifikansi yang dihasilkan adalah $<0.005$. Dapat dikatakan bahwa meskipun partisipan penelitian ini memiliki kemampuan regulasi diri yang tinggi, hal tersebut tidak dapat dijadikan tolak ukur bahwa mahasiswa yang mengikuti program mentoring akan memiliki prestasi akademik yang tinggi.

Uji hipotesis kedua menyatakan bahwa kecerdasan intelektual (IQ) tidak berperan terhadap pencapaian prestasi akademik. Hasil uji peran kecerdasan intelektual (IQ) terhadap prestasi akademik dapat dilihat pada tabel 2 .

Tabel 2. Uji regresi linear berganda pada variabel kecerdasan intelektual terhadap prestasi akademik

\begin{tabular}{lllll}
\hline \multicolumn{1}{c}{ Variabel } & R square & $\begin{array}{c}\text { Std. Error of the } \\
\text { estimates }\end{array}$ & F & Signifikansi \\
\hline $\begin{array}{l}\text { Kecerdasan } \\
\text { Intelektual (IQ) }\end{array}$ & 0.000 & 0.21002 & 0.016 & 0.901 \\
\hline
\end{tabular}


Nilai signifikansi pengaruh regulasi diri terhadap prestasi akademik sebesar 0.901. Artinya, dapat dikatakan bahwa meskipun partisipan penelitian ini memiliki kecerdasan intelektual (IQ) yang tinggi, hal tersebut tidak dapat dijadikan tolak ukur bahwa mahasiswa yang mengikuti program mentoring akan memiliki prestasi akademik yang tinggi.

Uji hipotesis ke-3 diperlihatkan pada tabel 3 yang menggambarkan hasil uji peran regulasi diri dan kecerdasan intelektual (IQ) secara bersama-sama terhadap pencapaian prestasi akademik

Tabel 3. Uji pengaruh regulasi diri dan kecerdasan intelektual terhadap prestasi akademik

\begin{tabular}{lllrc}
\hline \multicolumn{1}{c}{ Variabel } & \multicolumn{1}{c}{ R square } & Std. Error of the estimates & F & Signifikansi \\
\hline Regulasi Diri dan & 0.041 & 0.20800 & 0.946 & 0.396 \\
Kecerdasan & & & & \\
Intelektual & & & & \\
\hline
\end{tabular}

Berdasarkan hasil analisa yang dilakukan melalui uji korelasi Spearman, diketahui bahwa nilai signifikansi pengaruh regulasi diri dan kecerdasan intelektual (IQ) terhadap prestasi akademik adalah 0,396 ( $\mathrm{p}>0.05)$. Hal ini menunjukkan bahwa kemampuan regulasi diri maupun kecerdasan intelektual (IQ) secara bersama-sama tidak berpengaruh terhadap pencapaian prestasi akademik mahasiswa yang mengikuti program mentoring di Universitas X Tangerang.

\section{KESIMPULAN, DISKUSI DAN SARAN}

Kesimpulan yang dapat ditarik dari hasil penelitian ini adalah bahwa kemampuan regulasi diri dan kecerdasan intelektual (IQ) tidak berpengaruh terhadap pencapaian prestasi akademik partisipan. Hal ini menunjukkan bahwa hipotesa dalam penelitian ini ditolak.

Dapat diartikan bahwa mahasiswa yang mengikuti program mentoring serta berperan sebagai mentee di Universitas X Tangerang, mengalami penurunan prestasi akademik bukan karena disebabkan oleh faktor kemampuan mereka dalam melakukan regulasi diri maupun faktor kecerdasan intelektual (IQ) yang dimilikinya. Dengan kata lain, Mahasiswa yang mengikuti program mentoring dan berperan sebagai mentee di Universitas $\mathrm{X}$ Tangerang mengalami penurunan prestasi akademik karena disebabkan oleh berbagai faktor lain yang tidak diteliti dalam penelitian ini.

Beberapa hal yang mungkin dapat dijadikan sebagai bahan pertimbangan penyebab lain dari tidak terjawabnya hipotesa penelitian ini dapat dijabarkan sebagai berikut: Pertama, penyebaran kuesioner regulasi diri dan alat tes CFIT untuk mengukur kemampuan IQ partisipan dilakukan secara klasikal di dalam ruangan tertutup sehingga pengambilan data diobservasi langsung oleh peneliti dan expert. Sehingga peneliti dapat memastikan bahwa partisipan penelitian menjawab dengan sungguh-sungguh.

Kedua, Peneliti berpendapat bahwa prestasi akademik mahasiswa yang menjadi partisipan penelitian ini adalah partisipan yang memiliki prestasi akademik dengan kategori rendah, nonregular. Sehingga meskipun hasil penelitian ini menunjukkan bahwa kemampuan regulasi diri dan kecerdasan intelektual (IQ) partisipan berada dalam kategori sedang atau tinggi, hal tersebut tidak akan memengaruhi pencapaian prestasi akademiknya. 
Ketiga, berdasarkan data sekunder yang diperoleh Peneliti melalui wawancara dengan beberapa partisipan, diketahui bahwa partisipan penelitian ini merasa bahwa jurusan yang dijalaninya saat ini bukan merupakan pilihannya, melainkan karena arahan orangtua atau pun karena mengikuti teman semasa SMA. Hal ini membuat partisipan menjadi kurang tertarik untuk mendalami perkuliahan lebih lanjut. Selain itu, mahasiswa yang menjadi mentee pada program mentoring ini juga sebagian besar memiliki kegiatan lain di luar perkuliahan, seperti bekerja part time atau mengikuti kegiatan kemahasiswaan lain, sehingga partisipan menjadi kesulitan untuk mengarahkan kegiatannya pada upaya untuk mencapai prestasi akademik sesuai dengan standar yang ditentukan Universitas.

Berdasarkan analisis data sekunder, peneliti menemukan bahwa faktor eksternal cukup mempengaruhi prestasi akademik mahasiswa. Cara mengajar dosen yang menurut mahasiswa monoton, dosen hanya membaca slide presentasi, memberikan tugas tanpa menjelaskan materi secara detail, membuat mahasiswa tidak tertarik untuk memahami materi perkuliahan lebih dalam. Tarmidi mengatakan "iklim kelas yang positif berkorelasi positif dengan perubahan tingkah laku dan hasil belajar siswa," (Zetra Hainul Putra dan Wulan Sucitra, 2015, p.4). Dengan kata lain, iklim kelas merupakan salah satu cara untuk meningkatkan efektifitas dan kualitas pembelajaran di kelas.

Tidak adanya peran kecerdasan intelektual (IQ) terhadap prestasi akademik juga pernah ditemukan dalam penelitian yang dilakukan oleh Malik (2002). Pada hasil penelitiannya, Malik (2002) menemukan bahwa kontribusi intelegensi terhadap prestasi akademik cukup rendah. Hal ini diperkuat oleh Ali Khomsan yang berpendapat bahwa "anak dengan prestasi yang baik, saat diuji intelegensinya hanya mendapatkan skor biasa-biasa saja karena IQ yang diperoleh seseorang dari tes intelegensi pada suatu waktu tidak menjadi label yang selalu melekat pada diri individu, selain itu kondisi fisik dan psikologis individu sewaktu dikenai tes akan banyak berpengaruh pada hasil tesnya," (Zetra Hainul Putra dan Wulan Sucitra, 2015, p.13).

Bagi penelitian selanjutnya, peneliti menyarankan agar penelitian selanjutnya dapat melakukan penelitian untuk menguji pengaruh dari masing-masing aspek regulasi diri terhadap pencapaian prestasi akademik. Peneliti juga menyarankan agar penelitian selanjutnya dapat menggunakan sampel mahasiswa dalam kategori yang lebih luas agar hasil penelitian dapat digeneralisasi, sehingga dapat menjadi masukan bagi ilmu pengetahuan, khususnya bagi ilmu psikologi. Penelitian selanjutnya juga dapat dilakukan dalam bentuk penelitian eksperimental sehingga terdapat kontrol terhadap regulasi diri dan kecerdasan intelektual (IQ) partisipan.

Bagi penyelenggara pendidikan, peneliti menyarankan agar pihak Universitas dapat mengembangkan program-program yang diarahkan untuk mengembangkan softskills mahasiswa yang dapat mempengaruhi pencapaian prestasi akademik mahasiswa seperti kegiatan tentang motivasi dan minat mahasiswa terhadap perkuliahan dan jurusan yang diambil. Kegiatan ini juga dapat dilakukan melalui seminar atau workshop yang membangun motivasi mahasiswa, semisal dengan mendatangkan pembicara yang terkait dengan jurusan yang sudah mereka ambil saat ini.

Bagi mahasiswa sebagai partisipan penelitian, peneliti menyarankan agar mahasiswa khususnya yang mengikuti program mentoring di Universitas $X$ Tangerang dapat membuat target atau rencana studi pada setiap semester yang akan dijalani. Pembuatan rencana studi ini dapat dilakukan dengan arahan konselor terkait, sehingga selain membuat rencana studi, mahasiswa juga dapat membuat strategi-strategi untuk mencapai target studi yang sudah dibuat. Setelah 
membuat target studi, mahasiswa juga harus dapat berkomitmen dengan tujuan utama mereka dalam menjalani perkuliahan, sehingga selama menjalani kegiatan perkuliahan mahasiswa tetap dapat mengarahkan perilaku dan kegiatannya untuk fokus mencapai prestasi akademik sesuai standar yang ditetapkan universitas.

\section{Ucapan Terima Kasih (Acknowledgement)}

Peneliti mengucapkan terima kasih kepada seluruh pihak-pihak yang mendukung penelitian ini, diantaranya para Dosen Penguji yang sudah memberikan masukan dalam proses pengujian terhadap hasil penelitian ini. Peneliti juga mengucapkan terima kasih kepada kedua Dosen Pembimbing yang sudah memberikan masukan kepada Peneliti selama melakukan penelilian ini. Akhirnya, Peneliti juga tidak lupa mengucapkan terima kasih kepada Universitas X Tangerang, khususnya pada bagian Student Advisory and Development Center yang telah mengizinkan peneliti untuk mengambil data dan melakukan penelitian ini. Terima kasih juga kepada seluruh partisipan penelitian yaitu pada mahasiswa/mahasiswi yang berperan sebagai mentee dalam program mentoring di Universitas X Tangerang.

\section{REFERENSI}

Artana, M. B., Herawati, N T., Wikrama, Ananta., Atmadja, Tungga. (2014). 'Pengaruh Kecerdasan Intelektual (IQ), Kecerdasan Emosional (EQ), Kecerdasan Spiritual dan Perilaku Belajar Terhadap Pemahaman Akuntansi'. Journal Akuntansi Universitas Pendidikan Ganesha.

Dwijayanti, Arie Pangestu. (2009). Pengaruh Kecerdasan Emosional, Kecerdasan Intelektual, Kecerdasan Spiritual dan Kecerdasan Sosial Terhadap Pemahaman Akuntansi. (Unpublished master's thesis). Universitas Pembangunan Nasional "Veteran" Jakarta.

Gavora, Peter., Jake, Jitka., Kalenda, Jan. (2015). 'The Czech Validation of the Self-Regulation Questionnaire'. Journal of Procedia - Social and Behavioral Sciences, 171: 222-230. DOI: 10.1016/j.sbspro.2015.01.113.

Husna, Aftina Nurul., Hidayati, Frieda N.R., Ariati, Jati. (2014). 'Regulasi Diri Mahasiswa Berprestasi'. Journal Psikologi Universitas Pangeran Diponegoro.

Miller, W. R., Brown, J. M. (1991). Self Regulation as a Conceptual Basis for the Prevention and Treatment of Addictive Behaviors. Sydney: Maxwell Macmillan Publishing.

Newman, B.M. and Newman, P.R. (2009). Development Through Life: A Psychological Approach. Berlmont: Wadsworth Cengage Learning.

Pusat Bahasa Indonesia. (2005). Kamus Besar Bahasa Indonesia 3rd edition. Jakarta: Departemen Pendidikan Nasional Balai Pustaka.

Santrock, John W. (1999). Life-span Developmental $7^{\text {th }}$ ed. USA: McGraw Hill.

Zimmerman, B.J. (2000). Attaining self-regulation. Dalam M. Boekaerts, P.R. Pintrich, \& M. Zeidner (Eds.), Handbook of sef-regulation. San Diego: Academic Press. 